"TURYZM" 1992, z. 2

\title{
Jerzy Stejskał
}

PODMIEJSKIE REZYDENCJE BURZUUAZJI ŁÓDZKIEJ

I ICH FUNKCJE WYPOCZYNKOWE

DAWNIEJ I OBECNIE*

LES RESIDENCES SUBURBAINES DE LA BOURGEOISIE DE EOD'Z ET LEUR FONCTION DE REPOS JADIS ET A L'HEURE ACTUELLE SUBURBAN RESIDENCES OF THE ŁÓDŹ BOURGEOISIE AND THEIR FORMER AND PRESENT RECREATIONAL FUNCTIONS

Artykuł jest próbą prześledzenia procesu powstawania rezydencji podmiejskich łódzkiej burżuazji w oparciu o materiały archiwalne i badania terenowe. Przedstawione zostało rozmieszczenie obiektów w strefie podmiejskiej, przemiany funkcjonalne oraz próba typologii rezydencji w celu odnalezienia pierwowzoru powstających masowo po II wojnie światowej "drugich domów".

\section{ZAGADNIENIA WSTĘPNE}

Celem pracy jest znalezienie odpowiedzi na pytanie: gdzie wypoczywali zamożni mieszkańcy przedwojennej Łodzi, jak wyglądały i jaką rolę odgrywały $w$ ich życiu rezydencje podmiejskie, a także jakie były dalsze losy tych obiektów.

Praca jest próbą weryfikacji hipotezy badawczej, w myśl której zjawisko posiadania rezydencji podmiejskiej przez przedstawicieli burżuazji

* Artykuł powstał w oparciu o prace magisterska przygotowaną przez autora na seminarium z geografii turyzmu w Zakładzie Geografii Miast i Turyzmu IGEiOP Uniwersytetu Łódzkiego. 
łódzkiej sięgające końca XIX w., było pierwowzorem powszechnego dziś procesu powstawania tzw. „drugich domów” w okolicach dużych miast.

Zakres pracy traktować należy w dwóch wymiarach: czasowym i przestrzennym. Z uwagi na retrospektywny charakter pracy niezbędne było zebranie informacji z okresu, gdy powstawały pierwsze rezydencje, w celu prześledzenia przemian funkcjonalnych, jak również przedstawienia sposobu wykorzystania obiektów w różnych okresach ich istnienia. Tak rozumiany, czasowy zakres pracy, obejmuje okres około stu pięćdziesięciu lat, tj. od połowy XIX w. do roku 1990, gdy przeprowadzono badania i inwentaryzację obiektów.

Zakres przestrzenny obejmuje strefę podmiejską Łodzi, którą zdefiniowano jako obszar sąsiadujący z miastem, powiązany z nim systemem współzależności funkcjonalnych i zróżnicowany pod względem przestrzennym w wyniku oddziaływania miasta oraz sił i środków istniejących w nim samym (M a tczak 1985). Tak zdefiniowany obszar obejmuje powierzchnię 1903,75 km², a jego granicę zewnętrzną stanowi okrąg o promieniu $25 \mathrm{~km}$ zakreślony z centrum Łodzi, wewnętrzną zaś -- granice administracyjne miasta $\mathrm{z}$ okresu międzywojennego.

Przedmiotem pracy są obiekty pełniące przez pewien okres swego istnienia funkcję podmiejskich rezydencji burżuazji łódzkiej. W pracy tej za rezydencję podmiejską uważać będziemy obiekt wolno stojący w otoczeniu zieleni, w momencie budowy znajdujący się poza granicami administracyjnymi miasta, nie dalej jednak niż $25 \mathrm{~km}$ od jego centrum. Właścicielem i użytkownikiem obiektu był należący do burżuazji przemysłowiec lub kupiec, na stałe mieszkający w Eodzi. Analizie poddano warunki lokalizacji obiektów, ich historię, architekturę oraz sposoby wykorzystania zarówno przed, jak i po II wojnie światowej.

Proces zbierania materiału składał się z dwóch etapów: poszukiwań archiwalnych i bibliotecznych oraz badań terenowych. Pierwszy etap obejmował próbę znalezienia wskazówki dotyczącej właściciela i miejsca lokalizacji rezydencji na podstawie materiałów źródłowych, opracowań oraz informacji ustnych. Etap drugi stanowiła weryfikacja uzyskanych informacji $\mathrm{w}$ terenie oraz poszukiwanie i opis innych obiektów na podstawie rozmów przeprowadzanych w urzędach gmin i wśród mieszkanców.

Zbieranie materiału oparte było na karcie ewidencji zabytków architektury i budownictwa, wykorzystywanej w Pracowni Konserwacji Zabytków w Łodzi, obejmującej podstawowe cechy architektoniczne inwentaryzowanych obiektów, jak również ich historię i sposób użytkowania od momentu powstania do chwili obecnej, wzbogaconej ponadto 0 informacje dotyczące otoczenia opisywanej rezydencji. 
Inwentaryzacja architektoniczno-funkcjonalna objęła 33 obiekty spośród 35, które zidentyfikowane zostały jako rezydencje podmiejskie burżuazji łódzkiej (dwa obiekty obecnie nie istnieją). Brak materiałów pisanych dotyczących badanego zagadnienia wyklucza możliwość stworzenia absolutnie kompletnego katalogu takich budynków, jednak wywiady przeprowadzone $\mathrm{z}$ przedstawicielami dawnej burżuazji, jak również osobami zajmującymi się podobną problematyką ${ }^{1}$, pozwalają na stwierdzenie, iż materiał obejmujący pałace i dworki jest kompletny. Istnieje natomiast możliwość odnalezienia mniej okazałego obiektu, który mógłby być zaliczony do grupy rezydencji podmiejskich.

\section{SRODOWISKO NATURALNE JAKO PODSTAWA WYPOCZYNKU}

Rozpatrując obszar województwa łódzkiego w granicach z roku 1975 można dojść do przekonania, że teren ten już w odległej przeszłości upodobali sobie książęta i biskupi jako miejsce letniego pobytu, budując dwory myśliwskie i zwierzyńce, zamki i pałace (O la c zek 1974).

Łowicz powstanie swe zawdzięcza gródkowi myśliwskiemu książąt mazowieckich, który później stał się letnią rezydencją arcybiskupa i prymasów (O la c z e k 1974). Nie można zapomnieć o Spale, która stała się ulubioną rezydencją carów Rosji - Aleksandrów II i III, a także prezydentów Rzeczypospolitej (L iszewski 1991). Dużą sławą cieszyły się Nowe Miasto i Inowłódz, a także szereg miejscowości o charakterze wypoczynkowo-letniskowym, do których zaliczyć można Lisowice, Tworzyjanki, Bedoń, Gałkówek, Wiśniową Górę, Tuszyn czy Sokolniki (O l ac z e k 1974).

Przytoczone przykłady świadczą o dużym zainteresowaniu, także wśród mieszkańców Łodzi, otaczającymi miasto terenami w celu znalezienia dogodnych warunków do wypoczynku.

Współczesny krajobraz Łodzi i województwa łódzkiego jest rezultatem działania wielu złożonych procesów gospodarczych i społecznych, które dokonując się w określonym środowisku przyrodniczym, ze szczególnym nateżeniem w XIX i XX w., w znacznej mierze przekształciły jego elementy składowe (K o t e r 1988). Największym przemianom uległa pierwotna szata roślinna i świat zwierzęcy, a w konsekwencji tego również stosunki wodne oraz warunki glebowe. Przeobrażeń doznały, chociaż w mniejszym stopniu, pozostałe nieorganiczne składniki środo-

1 Informacji udzieliły m. in.: p. Doris Geyer z domu Biedermann, J. Piwkowska - siostrzenica p. Ireny Czylingarian, właścicielki willi w Moszczenicy oraz p. Joanna Bojarska. 
wiska naturalnego: rzeźba powierzchni, budowa geologiczna oraz klimat (Koter 1988).

Według wskaźnika zbiorczej atrakcyjności rekreacyjnej (M a tc za k 1986) strefa podmiejska Łodzi posiada przeciętne walory wypoczynkowe. Tereny o dostatecznych, dobrych i bardzo dobrych warunkach środowiska stanowią zaledwie $11,3 \%$ powierzchni strefy podmiejskiej i koncentrują się W 41 rejonach. Największe ich zgrupowania występują na północ od Łodzi, w strefie krawędziowej Wzniesień Łódzkich oraz nad górną i środkową Mrogą. Trzeci zwarty ciąg atrakcyjnych rekreacyjnie rejonów występuje w okolicach Tuszyna, Dłutowa i Łasku, a kolejny w obrębie trójkąta Aleksandrów-Szydłów-Konstantynów (M a t c z a k 1986).

\section{BURZ̈UAZJA EODZKA}

Głównymi warstwami, z których rekrutowała się burżuazja polska, były: miejscowe kupiectwo, rzemiosło i aktywizująca się gospodarczo część arystokracji i szlachty (K ołodzie jc zy k 1957). Na tle innych miast Łódź jawi się jako ośrodek o wyjątkowo czystej, kapitalistycznej strukturze ludności, żyjącej bezpośrednio z pracy $\mathrm{w}$ fabrykach, rękodzielniach, z kupiectwa i kramarstwa (K ołodzie j c z y k 1964).

Miejscowe kupiectwo było w swej zasadniczej masie pochodzenia bądź rodzimego - przeważnie żydowskie, bądź napływowe, rekrutujące się z Niemców (Kołodziejczyk 1979). Proces rozwoju kapitalistycznych stosunków produkcji doprowadzil do powstania klasy właścicieli podstawowych środków produkcji. Grupa ta, jakkolwiek zróżnicowana narodowościowo i religijnie, posiadała wiele cech wspólnych. Dzielił ją rozmiar posiadanego majątku, wielkość dochodów oraz sfera zastosowania kapitału, łączył wspólny interes przeciwstawiania się innym klasom społecznym oraz zbliżenie, pod względem wykształcenia, do inteligencji, wspólne zainteresowania i przyzwyczajenia (Kołodziejc z y k 1962).

Kultura intelektualna i materialna burżuazji łódzkiej uległa gruntownej przemianie w ciagu jednego zaledwie pokolenia. Pierwsze pokolenie to pionierzy - prekursorzy łódzkiej burżuazji. Gdy przybyli do Królestwa Polskiego w latach dwudziestych i trzydziestych XIX w., byli tylko zdolnymi rzemieślnikami, bez większych kapitałów, lecz z wielkimi ambicjami i planami na przyszłość. Nie mieli większego wykształcenia, nigdy też nie uzupełnili swej edukacji. Większość z nich zbankrutowała 
lub przedwcześnie zmarła, nieliczni jak Geyer, Heinzel, Scheibler czy Poznański dorobili się majątków ( $\mathrm{Z} \mathrm{a} \mathrm{wadzki} \mathrm{1974).}$

Drugie pokolenie - dzieci ,pionierów”, otrzymało z reguły gruntowne wykształcenie na wyższych uczelniach Europy, pozbyło się ciasnych mieszczańskich poglądów, stało się mecenasami sztuki. Do lat pięćdziesiątych ubiegłego wieku poziom życia łódzkich przedstawicieli burżuazji niewiele się różnił od poziomu zamożnego rzemieślnika, dopiero w latach sześćdziesiątych i siedemdziesiątych zaczęli otaczać się coraz więlkszym luksusem. Budowali eleganckie pałace, wille, zakładali parki, wyposażali mieszkania w drogie sprzęty, obrazy, bibeloty, nie szczędzili środków na stroje i ekwipaże - chcieli imponować potęgą swych pieniędzy.

Życie towarzysko-kulturalne $w$ Eodzi aż do połowy XIX w. praktycznie nie istniało. Wytężona praca oraz zamknięcie w obrębie grup narodowościowych powodowało obojętność na wiszystko, co wychodziło poza ramy twardej, codziennej pracy. Istniejące w tym czasie formy wypoczynku inspirowane były przez rzemieślników skupionych w cechach Dopiero w latach sześćdziesiątych i siedemdziesiątych burżuazja narzuca nowy styl bycia, w tym również wypoczynku. Trudno dziś stwierdzic, jakie formy wypoczynku preferowała burżuazja łódzka. Początkowo brak funduszy zmuszał ją do sporadycznych wyjazdów sobotnio-niedzielnych za miasto, do otaczających lasów dla świeżego powietrza (F l a t t 1863).

Zapewne wraz $\mathrm{z}$ rozwojem kontaktów $\mathrm{z}$ zagranicą, $\mathrm{tj}$. $\mathrm{w}$ latach siedemdziesiątych i osiemdziesiątych, rozpoczęła się moda na wyjazdy do zagranicznych kurortów i uzdrowisk Austrii, Szwajcarii, Włoch czy modnej, szczególnie w okresie międzywojennym, Ostendy. Inną formą wypoczynku były wyjazdy poznawcze wzorowane na podróżach arystokracji i burżuazji zachodnioeuropejskiej głównie do Włoch, Francji i Anglii.

Przed I wojną światową pojawiła się w okolicach Łodzi także nowa forma spędzania czasu wolnego, a mianowicie wyjazd na letnisko do pobliskich wsi, gdzie wynajmowano mieszkania u zamożnych rolników. Należy jednak zaznaczyć, że zjawisko to objęło raczej sfere inteligencji i kadry technicznej mieszkającej w Eodzi. Wielka i średnia burżuazja korzystała w tym czasie $\mathrm{z}$ wypoczynku poza granicami kraju. W okresie międzywojennym nasiliło się zjawisko budowy i przejmowania budynków w strefie podmiejskiej przez zamożną część społeczeństwa. Był to proces spowodowany z jednej strony zmianą ówcześnie panującej mody na wypoczynek, z drugiej zaś stosunkowo niewielkimi kosztami oraz szybkim dojazdem do własnej fabryki i możliwością przypilnowania interesów przedsiębiorstwa, 


\section{ROZMIESZCZENIE REZYDENCJI \\ W STREFIE PODMIEJSKIEJ EODZI}

Obszar badań obejmował strefę podmiejską Łodzi o powierzchni około $1900 \mathrm{~km}^{2}$ położoną $w$ promieniu $25 \mathrm{~km}$ od centrum miasta. $\mathrm{Na}$ tym obszarze zinwentaryzowano 35 obiektów zaliczonych do grupy rezydencji podmiejskich burżuazji lódzkiej, wśród których 2 budynki obecnie nie istnieją (tab. I).

Rezydencje usytuowane są w 22 rejonach atrakcyjnych dla wypoczynku, rozmieszczonych dość nierównomiernie w obrębie strefy podmiejskiej Łodzi. Spośród 35 obiektów 13 znajduje się na zachód od Łodzi, w tym aż 12 w dwóch miejscowościach - Porszewicach i Rąbieniu AB. Na północ od Łodzi zlokalizowano 7 rezydencji, wśród których 2 znajdują się na terenie Grotnik, a 3 przy drodze łączącej Ozorków i Stryków, w niewielkiej odległości od siebie. W południowej i wschodniej części strefy podmiejskiej znajduje się tylko 6 obiektów położonych w znacznej odległości od siebie (wyjątek stanowią Lisowice i Tworzyjanki usytuowane w odległości $3 \mathrm{~km}$ ).

W wyniku znacznego rozwoju przestrzennego Łodzi fo zakończeniu II wojny światowej 7 obiektów znajduje się w obrębie obecnych granic administracyjnych miasta. Pozostałe znajdują się na terenie $13 \mathrm{gmin}$, najwięcej w gminie Pabianice i Aleksandrów - po 6 obiektów - oraz Zgierz - 5 budynków.

Srednia odległość od centrum Łodzi do 22 micjsc, w których znajdują się rezydencje, mierzona. w linii prostej, wyncsi $14,4 \mathrm{~km}$. Biorąc pod uwagę ówczesny stan techniki i poziom rozwoju środków transportu (średnia prędkość pojazdów ok. $30 \mathrm{~km} / \mathrm{h}$ ) można stwierdzić, że tylko 4 obiekty znajdowały się $w$ strefie, gdzie czas dojazdu nie przekraczał $30 \mathrm{~min}$. Kolejnych 11 rezydencji dostępnych było w czasie 1 godz., a do pozostałych 20 dojechać można było w czasie nie przekraczającym 1,5 godz.

Dostępność komunikacyjina rezydencji warunkowana była także istaieniem odfowiedniej infrastruktury transportowej. Tylko 4 obiekty położone są w miejscowościach posiadających połączenie kolejowe z Łodzią, a 4 dalsze znajdują się $w$ pobliżu linii tramwajowej. Jednocześnie do 4 majątków, w których zlokalizowanych zostało 9 obiektów, w okresie międzywojennym prowadziła prywatna droga powstała $z$ inicjatywy i środków finansowych właściciela posiadłości. Ograniczoną popularność transportu szynowego tłumaczyć można posiadaniem przez właścicieli rezydencji środków transportu zapewniających szybki i wygodny dojazd. Utrudniony dojazd publicznymi środkami transportu stanowił również pewną barierę izolującą rezydencje burżuazji od miejsc wypoczynku mniej zamożnej części społeczeństwa Łodzi. 
Rezydencje podmiejskie burżuazji łódzkiej

Lesm résidences suburbaines de la bourgeoisie de Lódź

\begin{tabular}{|c|c|c|c|c|c|c|c|c|c|}
\hline Lp. & $\begin{array}{l}\text { Nazwa obiektu } \\
\text { dawny właściciel }\end{array}$ & $\begin{array}{c}\text { Miejsce } \\
\text { lokalizacji }\end{array}$ & Gmina & Województwo & Obecny właściciel & Użytkownik & $\begin{array}{c}\text { Rok } \\
\text { budowy }\end{array}$ & $\begin{array}{c}\text { Stan } \\
\text { techniczny }\end{array}$ & Otoczenie \\
\hline 1 & Willa Helmuta Biedermanna & Brus & m. Lódź & lódzkie & Skarb Państwa & Przedsiębiorstwo Ogrodnicze & ok. 1920 & & park, ogród \\
\hline 2 & Pałacyk Roemischa & Glowno & Glowno & dzkie & Skarb Państwa & Dom Dziecka & ok. 1920 & trwa przebudowa & las \\
\hline 3 & Pałacyk Alfreda Grohmanna & Gospodarz & Rzgów & lódzkie & Skarb Państwa & Gospodarstwo Ogrodnicze & po I wojnie & & park, las, staw \\
\hline 4 & Willa Artura Eisenbrauna & Grotniki & Zgierz & lódzkie & Skarb Państwa & Zakł. Przem. Baw. „Poltex” & 1935 & dobry & \\
\hline 5 & Dworek Pawła Biedermanna & Grotniki & Zgierz & lódzkie & osoba fizyczna & osoba fizyczna & lata trzydzieste & zly & las \\
\hline 6 & Dworek Karola Eiserta & Huta Dłutowska & Dłutów & piotrkowskie & Skarb Państwa & Dom Małych Dzieci & 1930 & trwa remont & \\
\hline 7 & Pałac Juliusza Heinzla ${ }^{a}$ & Julianów & m. Lódź & lódzkie & - & & ok. 1890 & & \\
\hline 8 & Willa Roberta Biedermanna & Kębliny & Zgierz & lódzkie & Skarb Państwa & osoba fizyczna & ok. 1930 & zly & \\
\hline 9 & Pałac Maurycego Hertza ${ }^{a}$ & Klęk & Stryków & łódzkie & - & + & ok. 1920 & & \\
\hline 10 & Pałac Sary Poznańskiej & Lisowice & Brzeziny & skierniewickie & Skarb Państwa & Dom Opieki Społecznej & XVIII/XIX w. & dobry & park, las, staw \\
\hline 11 & Pałac Heinzlów & Lagies & m. Lódź & lódzkie & Skarb Państwa & Szpital Chorób Phuc & ok. 1890 & dobry & park, las, staw \\
\hline 12 & Willa Alfreda Kindermana & Lódź-R & m. Lódź & lódzkie & osoba fizyczna & osoba fizyczna & ok. 1920 & zly & park \\
\hline 13 & Willa Juliusza Kindermana & Łódź- & m. Lódź & izkie & Skarb Pańs & Wydzial Oś & ok. & $\mathrm{zt}$ & $\mathrm{pa}$ \\
\hline 14 & Willa Artura Kindermana & kowa & m. \llcorner & ie & Skarb Państwa & Wydzial O & ok. & zh & park \\
\hline 15 & Dworek Fuksa & Lódź & m. Łódź & cie & Kościół Ew.-Aug. & osoba fizy & po I wojnie & & las \\
\hline 16 & Willa Ireny Czylingarian & Mos & Zgierz & lóc & Skarb Państwa & Zakłady "Maltex" & 1935 & dobry & las \\
\hline 17 & Willa Karola Steinerta & Porsze & Pabianice & lóc & Skarb Państwa & Dom Dziecka & ok. 1920 & zły & las \\
\hline 18 & Willa Karola Eiserta & Porszewice & Pabianice & łódzkie & Skarb Państwa & Dom D & ok. 1920 & dobry & las \\
\hline 19 & Willa Kindermana & Porszewice & Pabianice & łódzkie & Skarb Państwa & Dom Dz & ok. 1920 & dobry & la \\
\hline 20 & Dworek Ryszarda Steinerta & Porszewice & Pabianice & lódzkie & Skarb Państwa & Dom Dzi & ok. 1920 & dobry & las \\
\hline 21 & Dom podm. Edwarda Steinerta & Porszewice & ce & zkie & Skarb Państwa & Dom $\mathrm{Dz}$ & ok. 1920 & zl & las \\
\hline 22 & Dom podm. Ryszarda Steinerta & Porszewice & $\mathbf{P}$ & lóc & Skarb Państwa & Dom Dziecka & ok. 1920 & $z$ & las \\
\hline 23 & Willa Tuscha & Rąbień $\mathrm{AB}$ & ndrów & lódzkie & osoba fizyc & brak & ok. 1930 & ruin & las \\
\hline 24 & Willa Millera & Rąbień $\mathrm{AB}$ & Aleksa & łódzkie & Skarb Państwa & osoba fizyc & ok. 1930 & $\mathrm{zl}$ & las, \\
\hline 25 & Willa Glueksmana & Rąbień $\mathrm{AB}$ & Alek & łódzkie & osoba fizyczna & osoba fizy & ok. 1930 & dobry & las, \\
\hline 26 & Willa Zilkego & Rąbień & $\mathrm{Al}$ & łóc & osoba fizyc & osoba fizy & ok. 1 & & \\
\hline 27 & Willa Zilkego & Rąbień AB & Aleksa1 & lód & osoba fizyczna & osoba fizy & ok. 1930 & dol & las \\
\hline 28 & Willa Burmana & Rąbień $\mathrm{AB}$ & Aleksandrów & łódzkie & osoba fizyczna & osoba fizyczna & ok. 1930 & dobry & las, \\
\hline 29 & Dwór Maurycego Herbsta & Sokolniki & Ozorków & łódzkie & Skarb Państwa & Wiejski Ośrodek Zdrowia & pocz. XIX w & zly & las, 1 \\
\hline 30 & Pałacyk Daubego & Szynczyce & Czarnocin & piotrkowskie & Skarb Państwa & szkoła & pol. XIX w. & dobry & las, park, pola \\
\hline 31 & Dom podm. Karola Weikta & Tworzyjanki & Brzeziny & skierniewickie & osoba fizyczna & osoba fizyczna & ok. 1930 & dobry & las, park, pola \\
\hline 32 & Willa Henryka Gramsa & Wola Branicka & Zgierz & lódzkie & Skarb Państwa & Zakł. Odzieżowe „Próchnik” & ok. 1930 & dobry & \\
\hline 33 & Dworek Bulego & Zofiówka & Lutomiersk & sieradzkie & osoba fizyczna & osoba fizyczna & przed I wojną & ruina & las \\
\hline 34 & Dworek Oskara Langego & Zofiówka & Tuszyn & łódzkie & osoba fizyczna & osoba fizyczna & $1937-39$ & dobry & las, pola \\
\hline 35 & Willa Schwalbego & Żakowice & Koluszki & skierniewickie & Skarb Państwa & szkoła & 1930 & ruina & \\
\hline
\end{tabular}

a - Obiekt nie istnieje.

Źród lo: Opracowanie wlasne na podstawie badań terenowych. 
Przedwojenni właściciele rezydencji starali się w sposób optymalny wykorzystywać warunki środowiska naturalnego występującego w okolicach Łodzi (rys. 1). Wśród omawianych 35 obiektów tylko 8 znajduje

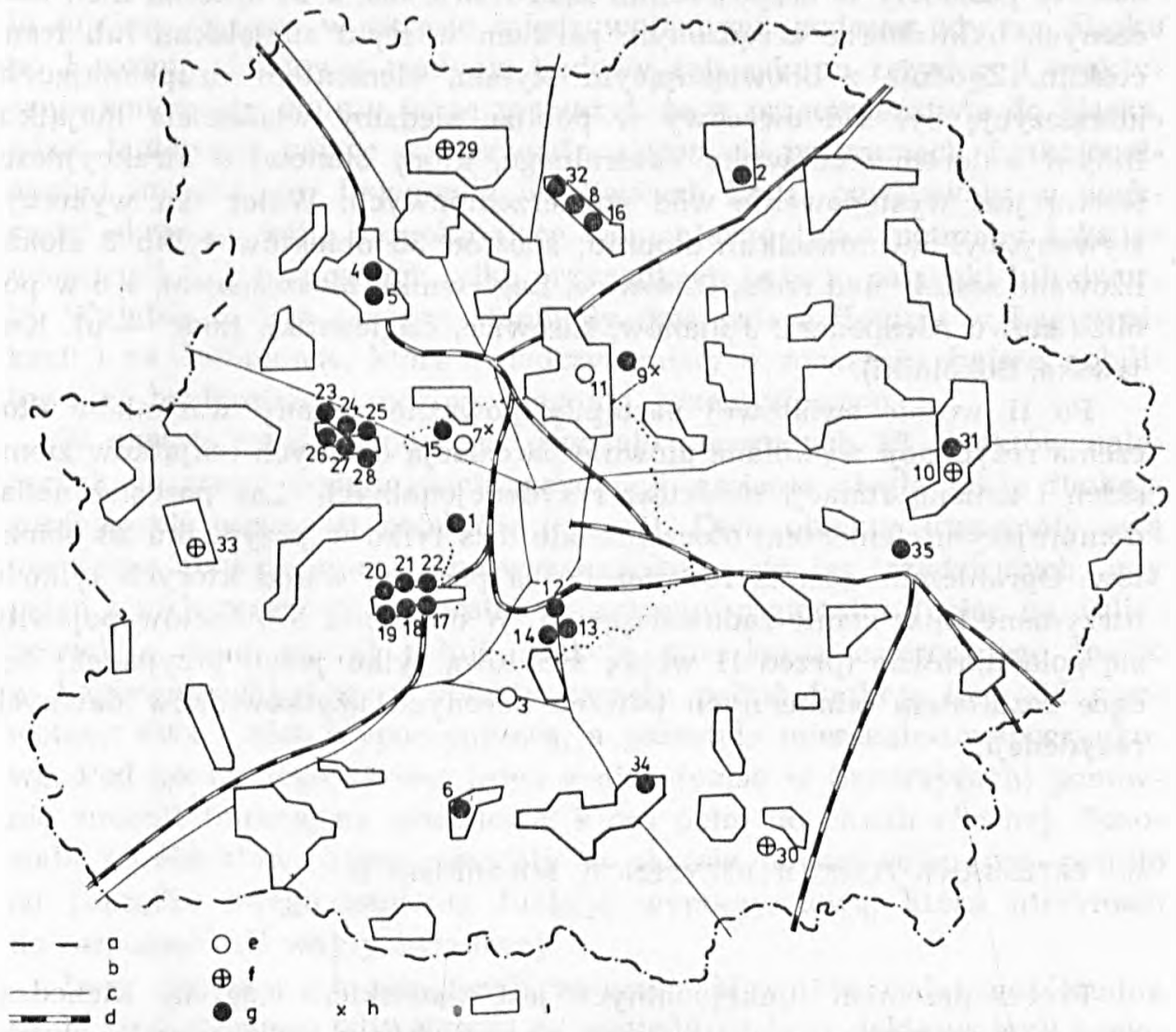

Rys. 1. Rozmieszczenie rezydencji burżuazji łódzkiej w strefie podmiejskiej Eodzi a - granice województw; b - granice Łodzi; c - główne drogi $i_{i}$ d - koleje; e - typ pierwszyi f - typ drugi; g - typ trzeci; h - obiekt nie istnieje; i - rejony atrakcyjne przyrodniczo (wg Matczaka); 1 - 35 patrz tab. I

Dcssin 1. Repartition des résidences de la bourgeoisie de Łódź dans la zone suburbaine de Łódź

a - limites des voïvodies; b - limites de Łódź; c - routes principales; d - chemins de fer;

e - premier type; $f$ - deuxième type; $g$ - troisième type; $h$ - objet n'existant plus; $\mathrm{i}$ - régions attrayantes du point de vue de la nature (d'après Matczak); $1-35$ voir Tabl. I

się poza rejonami najbardziej atrakcyjnymi przyrodniczo jako miejsce wypoczynku. W tej grupie 5 budynków zlokalizowanych zostało w obrębie dzisiejszych granic miasta, gdzie ze względu na intensywny rozwój przemysłu i budownictwa warunki śrcdowiska naturalnego uległy daleko idącym zmianom $\mathrm{w}$ porównaniu $\mathrm{z}$ okresem zakładania rezydencji. 
Równie starannie jak miejscowość, w której powstawała rezydencja, wybierane było lub zagospodarowywane bezpośrednie otoczenie obiektu. W okresie międzywojennym, gdy powstawała większość rezydencji, 34 obiekty posiadały w bezpośrednim sąsiedztwie las, a 20 spośród nich otoczonych było dobrze urządzonym parkiem $w$ stylu angielskim lub francuskim. Zgodnie z obowiązującym stylem, elementem uzupełniającym kompozycje był sad owocowy w pobliżu siedziby właściciela majątku. Innym walorem środowiska naturalnego, który stanowi o atrakcyjności terenu jest występowanie wód powierzchniowych. Walor ten wykorzystywany był w niewielkim stopniu; spośród 35 obiektów tylko 3 zlokalizowane zostały nad rzeką (Lisowice, Łagiewniki, Moszczenica), a $6 \mathrm{w}$ pobliżu stawu (Gospodarz, Julianów, Lisowice, Łagiewniki, Łódź -- ul. Kujawska, Sokolniki).

Po II wojnie światowej nastąpiły poważne zmiany warunków otoczenia rezydencji wywołane głównie parcelacją dawnych majątków ziemskich i zmianą funkcji obiektów rezydencjonalnych. Las pozostał nadal dominującym elementem otoczenia, ale dziś tylko w przypadku 28 obiektów. Ograniczona została również liczba parków, wśród których tylko 4 utrzymane sa w stanie zadowalającym. W otoczeniu 5 obiektów pojawiły się pola uprawne (przed II wojna światową tylko jeden przypadek) będące rezultatem odmiennych potrzeb obecnych użytkowników dawnych rezydencji.

5. PRZEMIANY FUNKCJI REZYDENCJI PODMIEJSKI H

Proces przemian funkcjonalnych jest zjawiskiem ciągłym, zachodzącym pod wpływem zmieniających się warunków politycznych, ekonomicznych, społecznych i kulturowych.

Przed I wojną światową w strefie podmiejskiej Łodzi istniało tylko 6 obiektów, które stały się później rezydencjami formującej się dopiero burżuazji łódzkiej. Dwa z nich powstały w końcu XIX w. i od początku swego istnienia pełniły funkcję mieszkalno-wypoczynkową (por. tab. I, nr 7,11 ). Pozostałe pełniły pierwotnie funkcję mieszkalną, były to dworki i pałacyki należące jeszcze $\mathrm{w}$ tym okresie do rodzin szlacheckich, ale jeden z nich (dworek w Sokolnikach) już w $1880 \mathrm{r}$. zmienił właściciela, stając się rezydencją wyfoczynkową łódzkiego przemysłowca Maurycego Herbsta.

Nowo powstająca klasa społeczna - burżuazja, zapożyczyła od arystokracji upodobanie do posiadania obok okazałego pałacu w mieście, letniej rezydencji otoczonej lasem i parkiem, często usytuowanej na tere- 
nie majątku ziemskiego. Zjawisko to na Sląsku obserwowano m. in. od lat siedemdziesiątych XIX w., gdzie wiązało się ze swoistą nobilitacją, bądź dążeniem do niej ludzi dorabiających się wielkich majątków².

W strefie podmiejskiej Łodzi podobne zjawisko w znacznej skali miato miejsce dopiero w okresie międzywojennym, podczas gdy na Sląsku po I wojnie światowej tradycja budowy lub zakupu rezydencji praktycznie kończy się. Należy także zauważyć, że w przeciwieństwie do Sląska, gdzie budowano pałace o niezwykle złożonych programach funkcjonalnych i imponującej fizjonomii, w okolicach Łodzi powstawały w większości skromne wille zaspokajające elementarne tylko potrzeby luksusu właścicieli, a w nielicznych tylko przypadkach były to pałacyki lub dworki. Wyjątek w tym zakresie stanowily dwa pałace Heinzla w Łagiewnikach i na Julianowie, które świadczyć miały o znaczeniu świeżo nobilitowanej hrabiostwem rodziny magnata przemysłowego.

W okresie międzywojennym powstało pozostałych 29 obiektów należących do grupy podmiejskich rezydencji, zmianie uległa także funkcja istniejących wcześniej obiektów (rys. 2). Dwa obiekty utrzymały swą pierwotną funkcję mieszkalno-wypoczynkową do lat trzydziestych, gdy jeden $z$ nich przeznaczony został na muzeum regionalne (pałac na Julianowie), a drugi zaczął pełnić funkcję mieszkania całorocznego (pałac w Łagiewnikach). Cztery obiekty zaczęły pełnić funkcję inną od pierwotnej; dwa z nich wypoczynkową, a pozostałe mieszkalno-wypoczynkowa. Pod koniec tego okresu jeden $\mathrm{z}$ nich (pałac w Szynczycach) ponownie zmienił funkcję na oświatową, którą pełni do chwili obecnej. Pozostałe 29 obiektów, które powstały w okresie międzywojennym, pełniło od początku swego istnienia funkcję wypoczynkową, którą utrzymało do rozpoczęcia II wojny światowej.

Losy omawianych rezydencji w czasie II wojny światowej trudne są do szczegółowego odtworzenia ze względu na brak dokumentacji i wiarygodnych informacji. W czasie działań wojennych poważnie uszkodzone zostały dwa obiekty, z których jeden rozebrano w 1945 r. (pałac na Julianowie), a drugi po zakończeniu działań wojennych (pałac w Klęku). Część pełniła sporadycznie funkcję wypoczynkową, inne wykorzystywane były przez wojska niemieckie. W jednym $\mathrm{z}$ nich (pałac w Eagiewnikach) urządzono szpital $\mathrm{z}$ pensjonatem dla przyszłych matek, a w drugim (pałac w Lisowicach) szpital dla rekonwalescentów armii niemieckiej. Kilka obiektów w czasie wojny było pustych, nie pełniły

2 Zagadnienia związane z zakładaniem rezydencji przez magnatów przemysłowych na Sląsku przedstawione zostały w pracy J. Suratowicza (1984). Znajdują się tam również informacje dotỵczące śląskiej rezydencji Karola Scheiblera w Blume Rhode (Kwietno), 

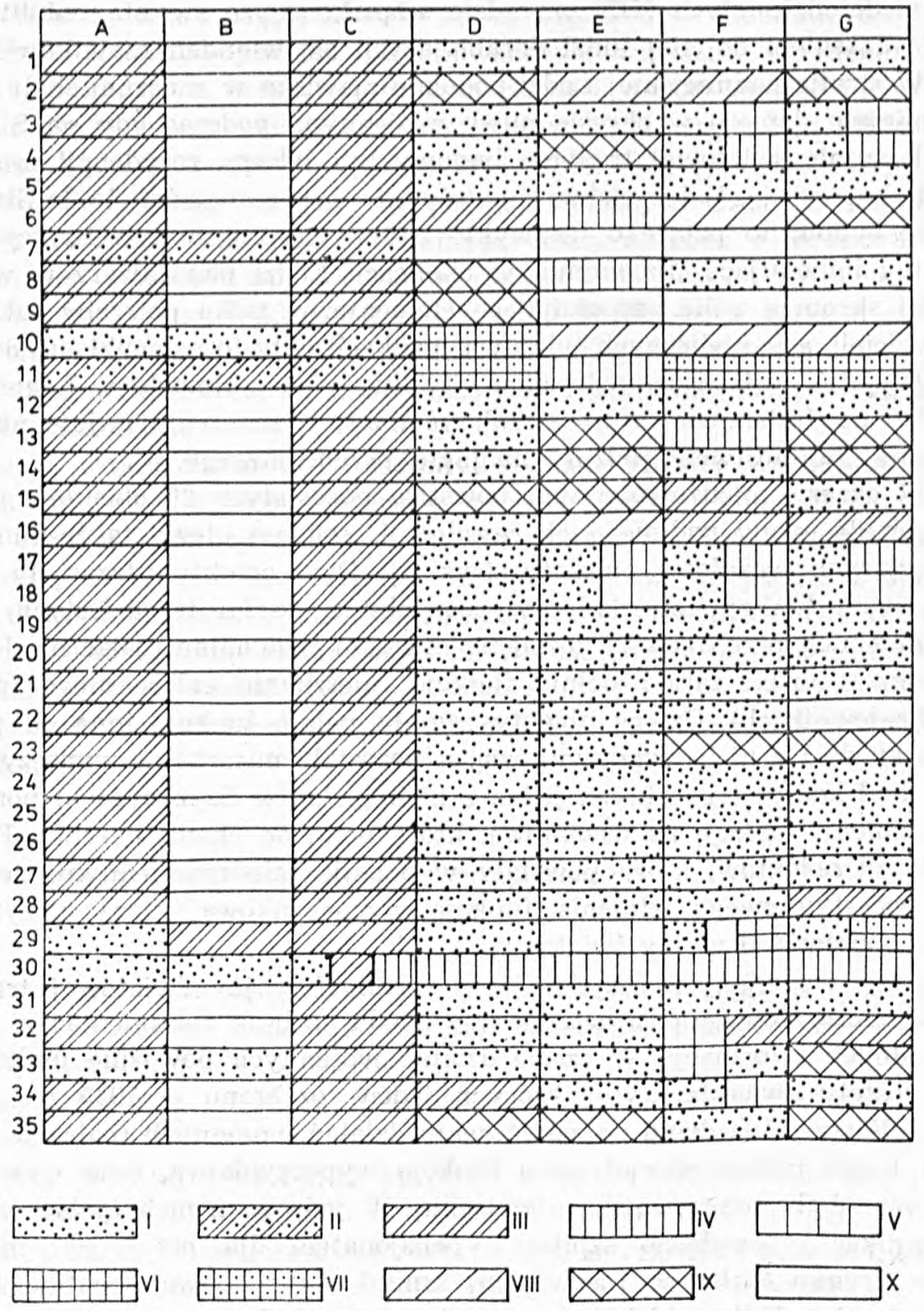

Rys. 2. Przemiany funkcji rezydencji podmiejskich burżuazji łódzkiej Etapy przemian funkcji badanych rezydencji: A - funkcja pierwotna, B - funkcja przed I wojną swiatowa, C - funkcja w okresie międzywojennym, D - funkcja w czasie II wojny światowej, E - funkcja bezpośrednio po zakończeniu wojny, F - funkcja w latach 1950-1989, G - funkcja W $1990 \mathrm{r}$.

1. Brus, 2. Glowno, 3, Gospodarz, 4, Grotniki, 5. Grołniki, 6. Hụta Dłutowşka, 7. Julịanów, 8. Kębliny, 
w tym okresie żadnych funkcji. Pałacyk w Szynczycach, który już w okresie międzywojennym pełnił funkcję oświatową, utrzymał ją także podczas okupacji niemieckiej.

Po zakończeniu II wojny światowej powstała całkowicie odmienna sytuacja ekonomiczna i społeczna. Dawne rezydencje, w dużej części opuszczone przez właścicieli, zmieniły całkowicie swe funkcje. Wzrastające zapotrzebowanie na mieszkania skłoniło kilka osób do zakupu stojących bezużytecznie budynków i zaadaptowania ich na mieszkania całoroczne. Także obiekty będące $\mathrm{w}$ gestii władz administracyjnych zostały zajęte w dużej części na potrzeby mieszkalne.

Bezpośrednio po zakończeniu działań wojennych 17 obiektów pełniło funkcję mieszkalną, 4 funkcję oświatową, a w 6 powstały domy opieki społecznej. Kilka budynków nie było wykorzystanych.

W okresie 1950-1990 nastąpiła kolejna zmiana funkcji i przeznaczenia niektórych obiektów. W czasie prowadzenia badań (lipiec-sierpień 1990 r.) dawne rezydencje pełniły następujące funkcje: mieszkalna 14 obiektów, wypoczynkowa - 3 obiekty, mieszkalna i administracyjna -2 obiekty, mieszkalna i oświatowa -2 obiekty, lecznictwo otwarte -1 obiekt, lecznictwo zamknięte -1 obiekt, opieka społeczna -1 obiekt. Sześć obiektów nie pełniło żadnej funkcji, w tym dwa były nie wykorzystane ze względu na brak funduszy przeznaczonych na remont, w dwóch dalszych prowadzony był remont kapitalny, a pozostałe trzy znajdowały się w stanie całkowitej ruiny (rys. 2).

9. Klęk, 10. Lisowice, 11. Łagiewniki, 12. Łódź-Raduńska, 13. Łódź-Letnískowa, 14. Łódź-Letniskowa, 15. Łódź Kujawska, 16. Moszczenica, 17. Porszewice, 18. Porszewice, 19. Porszewice, 20. Porszewice, 21. Porszewice, 22. Porszewice, 23. Rąbień $A B, 24$. Rąbień AB, 25. Rąbień AB, 26. Rąbień AB, 27. Rąbień $A B$, 28. Rąbień $A B$, 29. Sokolniki, 30. Szynczyce, 31. Tworzyjanki, 32. Wola Branicka, 33. Zofiówka, 34. Zofiówka, 35. Zakowice;

Funkcje badanych rezydencji: I - funkcja mieszkalna, II - funkcja mieszkalno-wypoczynkowa, III funkcja wypoczynkowa, IV - funkcja oświatowa, V - funkcja administracyjna, VI - lecznictwo otwarte, VII - lecznictwo zamknięte, VIII - opieka spoleczna, IX - brak funkcji, X - obiekt nie istnieje

Dessin 2. Changement de fonction des résidences suburbaines de la bourgeoisie de Łódź

Les étapes des transformations de fonction des résidences étudiées: A - fonction primitive, B fonction d'avant la rère guerre mondiale, C - fonction à l'époque d'entre deux guerres mondiales, D - fonction pendant la IIème guerre mondiale, E - fonction toute de suite après la fin de la guerre, F - fonction dans les années 1950-1989, G - fonction en 1990;

1. Brus, 2. Głowno, 3. Gospodarz, 4. Grotniki, 5. Grotniki, 6. Huta Dłutowska, 7. Julianów, 8. Kębliny, 9. Klęk, 10. Lisowice, 11. Łagiewniki, 12. Łódź-Raduńska, 13. Łódź-Letniskowa, 14. Eódź-Letniskowa, 15. Łódź-Kujawska, 16. Moszczenica, 17. Porszewice, 18. Porszewice, 19. Porszewice, 20. Porszewice,

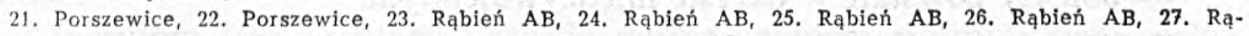
bień AB, 28. Rąbień $A B$, 29. Sokolniki, 30. Szynczyce, 31. Tworzyjanki, 32. Wola Branícka, 33. Zofiówka, 34. Zofiówka, 35. Zakowice;

Les fonctions des résidences étudiées: I - fonction d'habitation, II - fonction d'habitation et de repos, III - fonction de repos, IV - fonction d'instruction publique, V - fonction administrative, VI - thérapeutique ouverte, VII - trérapeutique fermée, VIII - assistance sociale, IX - sans fonction, $X$ - objet n'existe plus; 
W ramach procesu przemian funkcji rezydencji podmiejskich zauważyć można kilka prawidłowości:

1. Obiekty charakteryzujące się znaczną powierzchnią użytkową, otoczone lasem i parkiem przejęte zostały przez domy opieki społecznej ze względu na stosunkowo niski koszt adaptacji budynku do nowej funkcji oraz dogodne warunki otoczenia dla osób przebywających na terenie ośrodka.

2. Nieliczne obiekty odzyskały funkcję wypoczynkową w rezultacie przekazania ich po wojnie kierownictwom przedsiębiorstw, które dysponując odpowiednimi środkami finansowymi mogły zorganizować $w$ oparciu o istniejący obiekt ośrodek wypoczynkowy. Przed II wojną światową właścicielami tych obiektów byli właściciele lub udziałowcy zakładów, które przejęły wspomniane budynki.

3. Przeważająca liczba obiektów została zaadaptowana na mieszkania całoroczne przez ludność napływową bezpośrednio po wojnie lub nieco później przez okolicznych mieszkańców.

\section{TYPOLOGIA REZYDENCJI}

Dokumentacja faktograficzna zebrana podczas badań terenowych obejmuje szereg informacji z zakresu historii i architektury rezydencji podmiejskich burżuazji łódzkiej oraz warunków ich lokalizacji w środowisku geograficznym. Z uwagi na fakt, iż każdy z opisanych obiektów posiada własne, indywidualne cechy różniące go od pozostałych, niezbędny wydaje się podział zbiorowości na grupy charakteryzujące się podobieństwem cech stanowiących podstawę określonej klasyfikacji. Podział ten umożliwi uchwycenie powiązań między cechami przypisanymi grupie obiektów na podstawie różnych kryteriów, jak również pozwoli na próbę typologii rezydencji podmiejskich.

Poszukując odpowiedzi na pytanie, jakie były etapy powstawania rezydencji w strefie podmiejskiej Łodzi oraz jak rozwijała się funkcja wypoczynkowa okolic miasta $\mathrm{w}$ wyniku wzrostu zainteresowania wypoczynkiem podmiejskim ze strony zamożnej części społeczeństwa, analizowaną zbiorowość podzielić można na:

- obiekty powstałe w XIX w.;

- obiekty powstałe w okresie międzywojennym.

Kolejne kryterium klasyfikacji oparte na materiale historycznym pozwala na określenie sposobu, w jaki burżuazja łódzka stawała się właścicielem szeregu obiektów o charakterze rezydencjonalno-wypoczynkowym w strefie podmiejskiej. Można tu wyróżnić: 
- obiekty przejęte od szlachty;

- obiekty powstałe w miejscu istniejących wcześniej budynków;

- obiekty powstałe „na surowym korzeniu”.

W obrębie klasyfikacji, której kryterium stanowi status społeczny właściciela rezydencji wyróżnić można dwie grupy obiektów:

- należące do wielkiej burżuazji łódzkiej;

- należące do średniej i drobnej burżuazji.

Analizowana grupa obiektów zróżnicowana jest nie tylko pod względem genezy, ale także fizjonomii. Na tej podstawie wyróżniono cztery grupy obiektów:

- pałace i pałacyki;

- dwory i dworki;

- wille drewniane i murowane;

- domy podmiejskie.

W oparciu o sposób usytuowania obiektu w środowisku przyrodniczym wyróżniono dwie grupy:

- rezydencje usytuowane na terenie majątku ziemskiego;

- rezydencje usytuowane na parceli leśnej.

Jakkolwiek materiały archiwalne nie pozwalają na dokładne określenie powierzchni przedwojennych posiadłości, umożliwiają jednak zorientowanie się $\mathrm{w}$ skali zjawiska wykupu majątków ziemskich i przeznaczania ich na cele rekreacyjne.

Analizując preferencje lokalizacji rezydencji wyróżnić można grupy obiektów, w bezpośrednim sąsiedztwie których znajdował się:

- las;

- las i park;

- park i sad;

- las, park i sad;

- las, park i staw;

- las, park, sad i staw;

- las, rzeka lub staw.

$\mathrm{Na}$ podstawie przytoczonych kryteriów możliwa jest odpowiedź na pytanie, które $\mathrm{z}$ walorów środowiska przyrodniczego cenione były najbardziej.

Opierając się na przedstawionej klasyfikacji opracować można próbę typologii obiektów zaliczonych do grupy podmiejskich rezydencji burżuazji łódzkiej, biorąc także pod uwagę ich genezę oraz przemiany funkcjonalne.

Pierwszy typ - który określić można mianem podmiejskiego pała$\mathrm{cu}$ - reprezentują trzy obiekty założone w miejscu istniejących wcześniej budynków, rozebranych kilka lat przed rozpoczęciem budowy przyszlej rezydencji. Do grupy tej należą dwa pałace Juliusza Heinzla w La- 
giewnikach i na Julianowie (obecnie nie istnieje) oraz pałac Grohmana w Gospodarzu.

Dwie pierwsze rezydencje, powstałe jeszcze w XIX w., od początku swego istnienia pełniły funkcję mieszkalno-wypoczynkową, podobnie jak pałac w Gospodarzu wybudowany po I wojnie światowej. Właściciele tych rezydencji należeli do najzamożniejszych mieszkańców Łodzi, nic więc dziwnego, że starali się część swych fortun ulokować w majątkach ziemskich. Pałace Heinzla obok mieszkalno-wypoczynkowej pełniły także funkcję reprezentacyjną dla wzbogaconej i obdarzonej tytułem szlacheckim rodziny magnata przemysłowego.

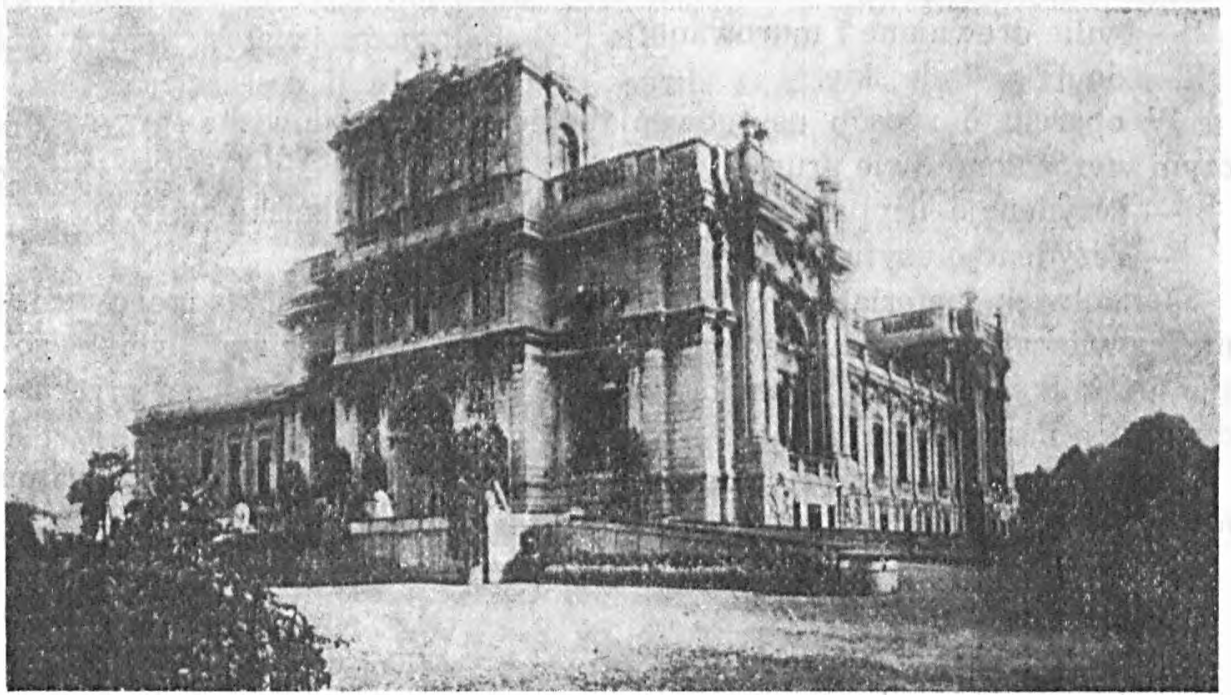

Fot. 1. Pałac Juliusza Heinzla na Julianowie (nie istnieje)

Photo 1. Le palais de Juliusz Heinzl à Julianów (n'existe plus)

Wraz z oryginalną i bogatą architekturą rezydencje otrzymały urozmaicone i doskonale utrzymane otoczenie, na które składał się rozległy las, park angielski i francuski, a także staw przystosowany do potrzeb rekreacji. Pałacyk w Gospodarzu, choć znacznie skromniejszy od przedstawionych powyżej, nie ustępowal im pod względem warunków lokalizacji, podobnie przystosowanych do zaspokajania potrzeb właściciela w zakresie wypoczynku.

Drugi typ, który określić można jako poszlacheckie dworki, reprezentują cztery obiekty przejęte przez burżuazję lódzką od szlachty w rezultacie zmieniającej się sytuacji społeczno-ekonomicznej, a także 


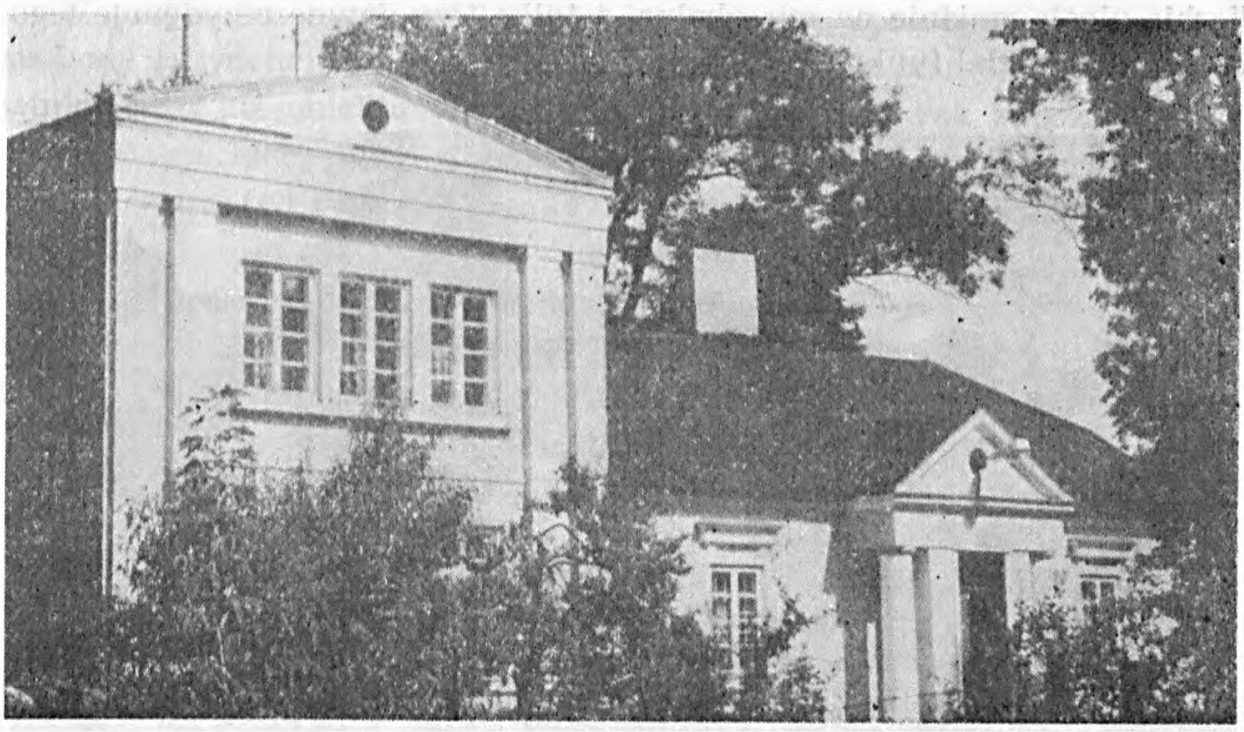

Fot. 2. Dwór Maurycego Herbsta w Sokolnikach

Photo 2. Le manoir de Maurycy Herbst à Sokolniki

panującej ówcześnie mody. Wspomniane obiekty powstały w XIX w. ale tylko jeden został przejęty przed I wojną światową. Wielkość zasobów właściciela nie była w tym przypadku decydująca, gdyż dokładnie taka sama liczba obiektów należała do wielkiej, jak i średniej burżuazji. Rezydencje charakteryzowały s.ę interesującą architekturą i stosunkowo dużymi rozmiarami budynku, zlokalizowane były na terenie majątków ziemskich, w bezpośrednim sąsiedztwie miały las, park, sad, a także staw przystosowany do wypoczynku. Wszystkie obiekty pelniły w okresie międzywojennym funkcję wypoczynkową, której jednak nie utrzymały po II wojnie światowej.

Trzeci typ obiektów, określony mianem willi podmiejskich, obejmuje 28 budynków powstałych „na surowym korzeniu”. Podobnie jak w poprzedniej grupie, zamożność właściciela nie była elementem decydującym o posiadaniu tego typu rezydencji. Pod względem fizjonomii przeważają drewniane i murowane wille. Obiekty należące do tego typu usytuowane były na terenie parceli leśnych zakupionych w niewielkiej odległości od Lodzi. Otoczenie ich było mniej urozmaicone. Przeważającym elementem środowiska przyrodniczego był las złożony $\mathrm{z}$ redzimych gatunków, komponujący się często z założeniami parku krajobrazowego. Wszystkie te obiekty pełniły w okresie międzywojennym funkcję wypoczynkową, która po II wojnie światowej w przeważającej 
liczbie uległa zmianie na mieszkalną, a tylko trzy dawne rezydencje tego typu pełnią nadal funkcję wypoczynkową.

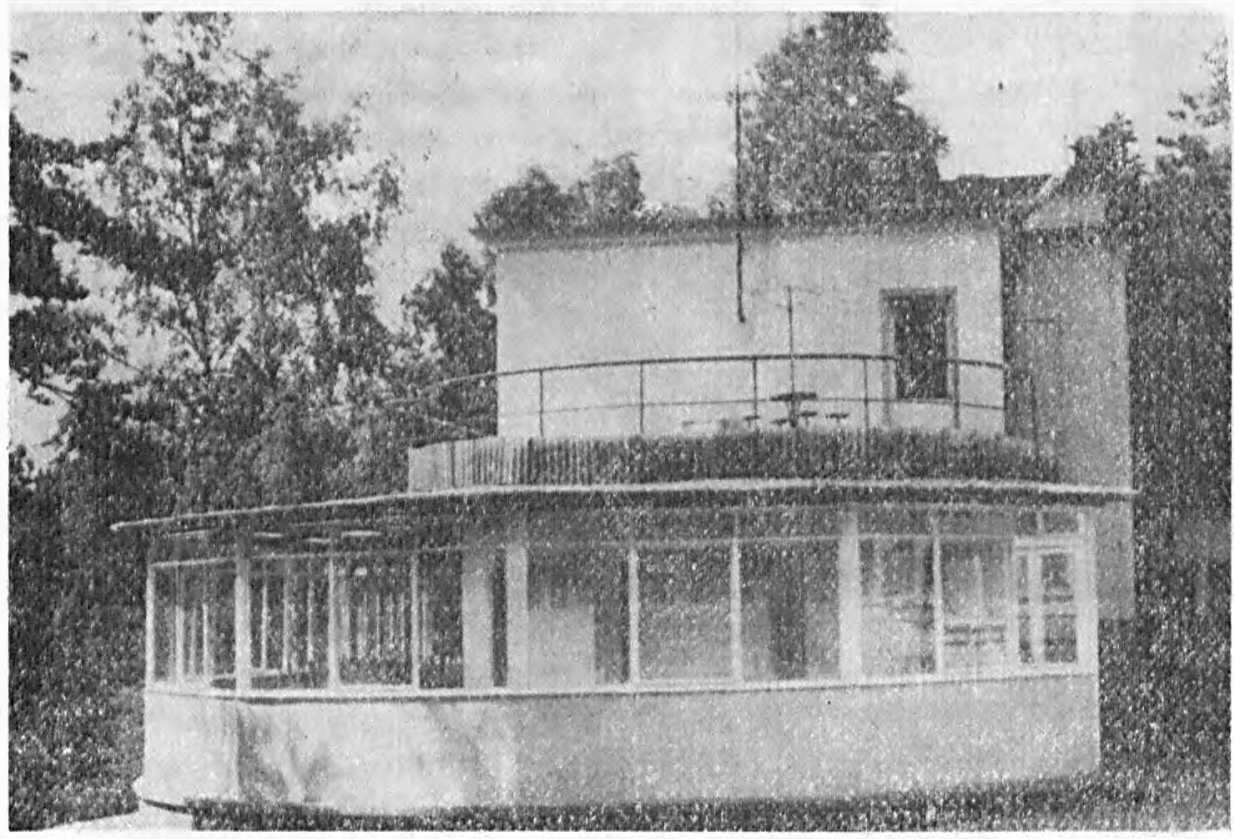

Fot. 3. Willa Ireny Czylingarian w Moszczenicy

Photo 3. La villa de Irena Czylingarian à Moszczenica

\section{PODSUMOWANIE}

Posiadanie przez burżuazję lódzką siedzib w strefie podmiejskiej Lodzi sięga końca XIX w. W tym czasie niektórzy jej przedstawiciele, posiadając odpowiednie środki finansowe, mogli je przeznaczyć na cele reprezentacyjne i wypoczynkowe. Początkowo ich ambicje zaspokajało posiadanie okazałej rezydencji miejskiej, bogato wyposażonej i otoczonej parkiem. Wypoczynek odbywał się poza granicami kraju, w modnych kurortach i kąpieliskach. Podezas licznych podróży zagranicznych łódzka burżuazja poznała inne jeszcze formy spędzania czasu wolnego, które oprócz możliwości wypoczynku podnosily rangę rodziny w opinii środowiska. Posiadanie rezydencji w strefie podmiejskiej Lodzi wraz z zakupem majątku ziemskiego stanowiło ponadto dobrą lokatę kapitału, jak również stwarzało możliwości wypoczynku bez konieczności odbywania dalekich podróży. 
W przypadku burżuazji lódzkiej istniały dwa sposoby wejścia w posiadanie rezydencji podmiejskich. Pierwszy z nich polegał na przejęciu istniejącego już obiektu wraz z całym majątkiem z rąk zubożałych rodzin szlacheckich. Wśród badanych dotyczy to tylko czterech obiektów, które w ten sposób zmieniły funkcję z mieszkalnej na wypoczynkową.

Drugi sposób polegał na budowie rezydencji od podstaw na terenie zakupionego majątku ziemskiego lub parceli leśnej. Zjawisko to zaistnialo praktycznie dopiero w okresie międzywojennym, chociaż dwa najbardziej okazałe pałace powstały jeszcze w XIX w.

Analiza przemian funkcjonalnych obiektów ze szczególnym uwzględnieniem funkcji wypoczynkowej prowadzi do wniosku, że większość z nich pełniła tę funkcję wyłącznie w okresie międzywojennym. Po wojnie dawne rezydencje przeksztalicone zostały $w$ mieszkania caloroczne lub przeznaczone na inne formy działalności, np. opiekę spoleczną. Tylko trzy dawne rezydencje pełnią nadal funkcję wypoczynkowa, w tym dwa przejęte zostały przez państwo po wojnie wraz z należącymi do burżuazji zakładami przemyslowymi.

Analiza etapów powstawania rezydencji w strefie podmiejskiej Lodzi pozwala na stwierdzenie, że zjawisko to, jakkolwiek zapoczątkowane już w końcu XIX w., rozwinęlo się dopiero po I wojnie światowej, nie osiągając jednak zbyt wielkich rozmiarów.

Porówñując proces powstawania rezydencji w okolicach Lodzi z podobnym zjawiskiem obserwowanym na Śląsku, zauważyć można pewne odrębności. Pierwszą z nich jest fakt opóźnienia w tym zakresie burżuazji łódzkiej, która rozpoczęła budowę większości rezydencji wtedy (po I wojnie światowej), gdy zjawisko to na Śląsku praktycznie zanikło. Rezydencje śląskie charakteryzowały się znacznymi rozmiarami, wyszukaną architekturą oraz skomplikowanym programem wnętrz. W strefie podmiejskiej Łodzi w większości powstały natomiast obiekty, których sposób wykorzystania i warunki lokalizacji były znacznie skromniejsze, przypominające raczej bardzo popularne obecnie tzw. „drugie domy".

Rezydencje podmiejskie burżuazji łódzkiej uznać można za pierwszą próbę wykorzystania strefy podmiejskiej przez mieszkańców Lodzi do budownictwa letniskowego, odbiegającego często w swej formie od spotykanego obecnie, ale będącego wzorem do naśladowania dla przedstawicieli inteligencji w okresie międzywojennym i pierwowzorem powszechnego obecnie zjawiska budowy ,drugich domów”. 


\section{PISMIENNICTWO}

Flatt O., 1853, Opis miasta Łodzi pod waględem historycznym, statystycznym i przemyslowym, Warszawa.

Kołodziejczyk R., 1967, Ksztcttowanie się burżuazji w Królestwie Polskim (1815-1850), PWN, Warszawa.

Kołodziejezyk R., 1962, Bohaterowie nieromantyczni. O pionierach kapitalizmu w Kroitslwie Polskim, Wiedza Powszechna, Warszawa.

Kolodziejczyk R., 1964, Ksztaftowanie się kapitalizmu na ziemiach poiski $n$ w latach 1796-1864, Wyższa Szkola Nauk Spolecznych, Warszıwa.

Kołodziejczyk R., 1979, Burżuazja polska w XIX i XX wieku. Szkice hisloryczne, PIW, Warszawa.

Liszewski S., 1987, Geneza i rozwój osadnictwa wypoczynkowego w otoczeniı Łodzi, "Acta Universitatis Lodziensis", Turyzm nr 5, Łódz.

Liszewski S., 19y1, Spala. Morfologia i iunkcja miejscowości wypoczynkowej, "Turyzm", t. 1, z. 2.

Koter M., 1988, Warunki naturalne, [w:] Łódź - dzieje miasta (red. R. Rosin), PWN, Warszawa.

Matczak A., 1985, Funkcje wypoczynkowe strefy podmiejskiej Łodzi, „Acta Universitatis Lodziensis", Folia Geogr. z. 5, Łódź.

Matczak A., 1986, Przyrodnicze podstawy organizacji wypoczynku w strefie podmiejskiej Łodzi, "Acta Universitatis Lodziensis", Turyzm nr 2, Łódź.

Olaczek R., 1974, Rejony turystyczne województwa lódzkiego na tle zasobności terenu w walory turystyczne, [w:] Region Eódzki. Studia i Materialy, t. 4, Łódż.

Suratowicz J., 1984, Materiały Muzeum Wnętrz Zabytkowych w Pszczynie, Pszczyna.

Mgr Jerzy Stejskał

Zakład Zagospodarowania Srodowiska

Wplynęlo:

i Polityki Przestrzennej

Uniwersytet Łódzki

al. Kościuszki 21

90-418 Łỏdź

\section{RESUMÉ}

Il faut rapporter à la fin du XIXème siècle l'apparition des premières résidences de la bourgeoisie de Łódź dans la zone suburbaine de la ville. A cette époque-la certains membres de cette classe disposant de moyens financiers suffisants pouvaient les destiner au repos ou aux objectifs de représentation. D'abord leurs ambitions étaient assouvies par la possession d'un palais somptueux ou les départs pour les stations balnéaires; plus tard, ils cherchaient à avoir une résidence dans le voisinage de la ville, qui, avec un domaine acquis, constituait un bon placement de capitaux, mettait en valeur l'importance de la famille dans les yeux du milieu.

Les recherches dans les archives et sur le terrain ont eu pour résultat la localisation des 35 résidences formant un groupe des résidences suburbaines de la bour- 
geoisie de Lódź (Tabl. I). Les objets sont disposés d'une façon inégale dans la zone suburbaine et se concentrent dans les régions les plus attrayantes pour le repos du point de vue de la nature, ce qui démontre le soin particulier des propriétaires quant au choix de l'entourage de la résidence bâtie.

Au cas de la bourgeoisie de Eódż, on devenait propriétaire d'une résidence suburbaine de deux manières. La première consistait en achat d'un objet déjà extistant, avec tout le bien, des mains de familles nobles appauvries. 1elle est l'origine des quatre résidences suburbaines seulement.

La deuxième manière consistait en construction de la résidence en entier sur le territoire du bien acquis ou d'une parcelle forestière. Pratiquement ce phénomène n'a pas pris naissance que dans la période d'entre deux guerres, bien que deux palais sonpıueux dient éte construits encore au XIXème siècle.

Le problème des évolutions fonctionnelles des objets mène à la conclusion, que la plus grande partie de ceux-ci avait la fonction de repos exclusivement dans la période d'entre deux guerres. Après la lième guerre mondiale, les anciennes résiaences ont eté transformees en appartements habités pendant toute l'année ou destinées aux formes dive.ses de l'activité, assistance sociale, p. ex. Seules 3 d'entre les résidences ont maintenu leur fonction de repos. 2 d'entre elles ont été appropriées par l'état avec les établissements indusiriels appartenant à l'ancie.. ne bourgeoisie (Dessin 2).

L'analyse des étapes de l'apparition des résidences dans la zone suburbaine permet de constater, que le phenomène, bien que inauguré dejà vers la fin du XIXème siècle, s'est déveioppé seulement dans la période d'entre deux guerresi même aiors il ne manifestait pas de grande vitalité (Tabl. I).

Seules quelques unes des 35 résidences inventorisées dans la région de Łódź se taisaient remarquer par l'opulence et le luxe démontrant leur caractère d'anoblissement el leur desination. La plupart des objets formant le groupe de résidences suburbaines avaient la physionomie d'une villa plus ou moins splendide, dont la façon d'exploitation et les conditions de la localisation rappelient les "secondes résidences" très répandues à l'heure actuelle.

Les résidences suburbaines de la bourgeoisie de Łódź peuvent être considérées comme le premier essai de tirer purti de la zone suburbaine fait par les habitants de Eódź pour là construction estivale, différente dans sa forme de celle qu'on rencontre à présent, mais servant de modèle à imiter aux représentants de l'intellígentsia à l'époque d'entre deux guerres et les constructeurs des „résidences secondaires" très nombreuses à l'heure actuelle.

Traduit par Lucjan Kowalski

\section{SUMMARY}

The beginnings of residences belonging to the local bourgeoisie in the suburban zone of Łodź date back to the late 19th century. At that time some of its representatives possessing adequate financial resources were able to earmark them for recreation and representation purposes. At first, they would be satisfied with possessing a splendid palace in the city and visiting the fashionable spas, but later on they wished to have their residence in the vicinity of the city, which along 
with the purchased landed estate constituted a good capital investment and ensured a higher social position of a family in the local milieu.

The analysis of the archives and field studies allowed to localize 35 residences of the bourgeolisie in the suburban zone of Łódź (Table I). The residences are scattered throughout the suburban zone, but they are concentrated in areas most attractive for recreational purposes (Fig. 1), which could be treated as a testimony of a great care exercised by their owners when selecting the site for a residence.

The Łódż bourgeoisie had two ways of coming into ownership of a suburban residence. The first of them consisted in taking over buildings and the entire estate from impoverished nobility families. In this way, only four suburban residen. ces were set up.

The other way involved building a residence "from the scratch" on an acquired landed estate or forest site. That phenomenon appeared practically not until the interwar period, although two most magnificent palaces were built still in the 19th century.

The analysis of the functional changes of the residences leads to the conclusion that most of them had a recreational function solely during the interwar period. After the war the former residences were transformed in year-round apartmen's or they were used for other purposes, e.g. welfare assistance. Only three of them perform a recreational function today, and among them two were taken over by the State along with industrial plants belonging to the former bourgeoisie (Fig. 2).

The analysis of stages in setting up residences in the suburban zone of Eodz shows that this phenomenon started still in the 19th century was not accelerated until the interwar period (Table I), but even then it did not assume any bigger scale.

Only a few from among the 35 residences in the suburban zone of Eodz distinguished themselves by affluence and splendour reflecting the wealth of their owners and their ennoblement character. However, most of the residences classified among the suburban residences looked like more or less sumptuous villas, which were used for purposes resembling those of the so-called "second homes" so popular today.

The suburban residences of the local bourgeoisie can be treated as the first attempt made by the inhabitants of Łódz to use the suburban zone for purposes of recreational housing departing quite considerably in their design and form from "second homes" erected by the intelligentsia in the interwar period and imitating the residences in question or those built these days.

Translated by Leszek Podbielski 